\title{
TRPM8 Agonist D-3263
}

National Cancer Institute

\section{Source}

National Cancer Institute. TRPM8 Agonist D-3263. NCI Thesaurus. Code C162345.

A small-molecule agonist for transient receptor potential melastatin member 8 (TRPM8 or Trp-p8), with potential antineoplastic activity. Upon administration, TRPM8 agonist D3263 targets, binds to and activates TRPM8, which may result in an increase in intracellular calcium and sodium influx; the disruption of calcium and sodium homeostasis; and the induction of cell death in TRPM8-expressing tumor cells. This agent may decrease dihydrotestosterone (DHT) levels, which may contribute to its inhibitory effects on prostate cancer and benign prostatic hyperplasia (BPH). TRPM8 is a transmembrane calcium channel protein that is normally expressed in prostate cells and appears to be overexpressed in BPH and in prostate cancer. 